UDC 577.218

\title{
Transcriptional and post-transcriptional regulation of the adaptor/scaffold protein gene ITSN1
}

\author{
S. V. Kropyvko ${ }^{1}$, O. S. Gubar ${ }^{1}$, T. A. Gryaznova ${ }^{1}$, D. Ye. Morderer ${ }^{1}$, \\ D. O. Gerasymchuk ${ }^{1}$, L. A. Syvak ${ }^{2}$, A. N. Grabovoy ${ }^{2}$, A. V. Rynditch ${ }^{1}$ \\ ${ }^{1}$ Institute of Molecular Biology and Genetics, NAS of Ukraine \\ 150, Akademika Zabolotnoho Str., Kyiv, Ukraine, 03680 \\ ${ }^{2}$ National Cancer Institute \\ 33/43, Lomonosova Str., Kyiv, Ukraine, 03022 \\ siryl_2000@yahoo.com
}

ITSN1 adaptor/scaffold protein takes part in a variety of physiological and pathological cellular processes. It has a complex expression regulation and many protein partners. Aim. Characterization of the ITSN1 functioning and expression control is important for understanding its role in cell. Methods. Bioinformatic analysis, semi-quantitative expression analysis by RT-PCR, immunoprecipitation. Results. We have described and analyzed the ITSN1 promoter regions, detected ITSN1 alternatively spliced isoforms at mRNA and protein levels in different cancer specimens. Using different bioinformatic servers, we have identified the sites for miRNA binding and analyzed the sites for serine, threonine and tyrosine phosphorylation of the ITSN1 protein. Conclusions. We have obtained new data on the ITSN1 expression in pathology. We have also shown the possibility of ITSN1 expression regulation by miRNA and phosphorylation of serine, threonine and tyrosine.

Ke y w o r d s: ITSN1, bidirectional promoter, alternative splicing, miRs, phosphorylation.

\section{Introduction}

ITSN1 is a multifunctional scaffold protein that is implicated in many cellular processes such as clathrin- and caveolin-mediated endocytosis, exocytosis, MAP kinase signaling, actin cytoskeleton rearrangements, membrane remodeling, etc. The ITSN1 gene is localized at chromosome 21 . It was shown that ITSN1 is involved in such neurodegenerative pathologies as the Down's syndrome, Alzheimer's and Huntington's diseases [1-3]. ITSN1 takes part in migration and invasion of human glioma cells and is localized in invadopodia, actin-rich protrusions that drive invasion in cancer cells [4, 5]. Three main ITSN1 isoforms are produced in human: long isoform ITSN1-L expressed mostly in nervous system, short isoform ITSN1-S and ITSN1-22a isoform which are ubiquitously expressed. ITSN1 is an adaptor protein with unique multidomain structure. ITSN1-L consists of two N-terminal EH domains (EH1 and EH2), coiled-coil region (CCR), five Src homology 3 domains (SH3A-E), Dbl homology $(\mathrm{DH})$, pleckstrin homology $(\mathrm{PH})$, and $\mathrm{C} 2$ domain. EH domains, CCR and SH3 domains interact with specific protein motifs: EH domains bind NPF motifs; $\alpha$-helix regions form dimers; SH3 domains bind proline-rich motifs (PxxP). DH domain is a guanine nucleotide exchange factor which activates a small GTPase Cdc42 from the Rho family. The main function of $\mathrm{PH}$ domain is considered to be the regulation of the DH domain and membrane localization of the protein via phosphoinositides binding [6]. However, the ITSN1 PH domain binds phosphoinositides but it neither influences guanine nucleotide exchange by

(C) 2016 S. V. Kropyvko et al.; Published by the Institute of Molecular Biology and Genetics, NAS of Ukraine on behalf of Biopolymers and Cell. This is an Open Access article distributed under the terms of the Creative Commons Attribution License (http://creativecommons.org/licenses/by/4.0/), which permits unrestricted reuse, distribution, and reproduction in any medium, provided the original work is properly cited 
DH nor, neither determines the subcellular localization of the protein $[6,7]$. The $\mathrm{C} 2$ domain is thought to take part in $\mathrm{Ca}^{2+}$-dependent phospholipid binding [8].

Due to the multiple alternative splicing events all other ITSN1 isoforms lack some domains or several amino acid residues. For instance, the short isoform ITSN1-S lacks the DH, PH and C2 domains and therefore does not have any enzymatic activity.

The majority of ITSN1 functions is performed by binding to its protein partners. At the moment, more than thirty ITSN1 partners are discovered, and this list is permanently increasing as well as the list of ITSN1-related processes. Regarding the complexity of the ITSN1 interactome, the regulation of ITSN1 gene expression and functioning is quite sophisticated and is fulfilled with the variety of mechanisms both at transcriptional and post-transcriptional levels $[9,10]$.

\section{Materials and Methods}

\section{Bioinformatical analysis}

For the Bioinformatical analysis we used GeneBank (http://www.ncbi.nlm.nih.gov/) andPhosphoSitePlus (http://www.phosphosite.org/homeAction.action) databases and the following servers and online utilities: UCSC Genome Browser on Human Dec. 2013 (GRCh38/hg38) Assembly (http://genome.ucsc.edu/ cgi-bin/hgTracks?db=hg38\&lastVirtModeType $=$ def ault\&lastVirtModeExtraState $=\&$ virtModeType $=$ default \&virtMode $=0 \&$ non VirtPosition $=\&$ position $=\mathrm{ch}$ r21\%3A33641275-33643785\&hgsid=497171239 NC 3 k 6 O a F Orw Ode B e W s 9 R x A Jn 2 qj 8 ), RepeatMasker (http://www.repeatmasker.org/), TargetScan (http://www.targetscan.org/vert_71/), MicroRNA.org (http://www.microrna.org/microrna/ getGeneForm.do), RegRNA 2.0 (http://regrna2.mbc. nctu.edu.tw/index.html).

\section{$R N A$ isolation and RT-PCR}

Total RNA from human tissues was isolated as described previously [11]. cDNA was synthesized from 1 to $5 \mu \mathrm{g}$ of total RNA using oligo $\left(\mathrm{dT}_{18}\right)$ primer and
RevertAid H Minus Reverse Transcriptase («Thermo Scientific», USA). Five percent of the cDNA obtained was used as a template for PCR as described previously [11]. The following oligonucleotides were used for the expression analysis of transcripts generated from an alternative promoter:

20 exon frw 2566-agtcatggttaaaggggaatgg-2587; 23 exon rev 3166-aactcgagcttgtagacttccttatg-3184; 23 exon frw 3112-gtggtggtttggaggagttcaagg-3135; 22 exon frw 2583-gcacgaatgagaaaccagaaacgg-2606; 22a exon rev 2891-gactttgacagctagggcttcgga-2868; 27 exon rev 3530-tggcggtgtatgaggcaataac-3509; 33 exon frw 4160-gcgetgagagtccgcaagaagat-4182; 34 exon frw 4394-ctgaagcctatgcaacgggtaac-4416; 39 exon rev 5122-gttgctctttcctagtgaccgac-5100; 41 exon rev 5307-atctccgtccgacccaaaaaatc-5285; frw GAPDH 5'-tgaaggtcggagtcaacggatttggt-3'; rev GAPDH 5'-catgtgggccatgaggtccaccac-3'; frw $\beta$-actin $5^{\prime}$-gaaatcgtgcgtgacattaag-3'; rev $\beta$-actin $5^{\prime}$-aagcatttgcggtggacgatggag- $3^{\prime}$.

Nucleotide positions for oligonucleotides are based on the ITSN1-L, ITSN1-S and ITSN1-22a cDNAs(GenBank accessionnumbers NM_003024.2, NM_001001132.1 and DQ386455).

\section{Cell culture, transfection \\ and immunoprecipitation}

MDA-MB-231 cell lines were cultured in Dulbecco's modified Eagle's medium (DMEM) supplemented with $10 \%$ fetal bovine serum, $50 \mathrm{U} / \mathrm{ml}$ penicillin and $100 \mu \mathrm{g} / \mathrm{ml}$ streptomycin. The cells were transiently transfected with PEI (polyethyleneimine) according to the manufacturer's instructions and processed $24 \mathrm{~h}$ after transfection. For immunoprecipitation (IP), the cells were lysed in IP buffer $(20 \mathrm{mM}$ Tris- $\mathrm{HCl} \mathrm{pH} 7.4,150 \mathrm{mM} \mathrm{NaCl}, 0.5 \%$ Nonidet P40, $10 \%$ glycerol, $2 \mathrm{mM}$ EDTA and protease inhibitor cocktail). The lysates were incubated with antibodies and protein A/G PLUS-Agarose («Santa Cruz Biotechnology», USA) prewashed in IP buffer. After incubation for $3 \mathrm{~h}$ at $+4{ }^{\circ} \mathrm{C}$, the beads were washed three times with IP buffer. Bound proteins were eluted by boiling in Laemmli sample buffer and then analyzed by SDS-PAGE and Western blotting. 


\section{Antibodies}

The mouse polyclonal antibodies against the DH-PH domains of human ITSN1 (anti-ITSN1-DH) were produced in mouse immunized with recombinant His-tagged protein comprising amino acid residues 1240-1575 of human ITSN1-L. The rabbit polyclonal antibodies against the EH2 domain of human ITSN1 (anti-ITSN1-EH2) were described previously [12]. The secondary horseradish peroxidase-labeled anti-rabbit antibodies were purchased from Promega.

\section{Results and Discussion}

\section{Promoter regions of human ITSN1 gene}

The ITSN1 gene has 246826 bp (NG_029504.1) and is localized on chromosome 21 locus q22.1-q22.2. The gene is comprised of 42 exons which influence the amino acid composition of the protein molecule. The expression regulation of ITSNI at the transcriptional level is performed by transcription from two different promoters and the generation of a vast majority of alternatively spliced mRNA isoforms. The main ITSN1 promoter, which gives rise to the most mRNAs, is a bidirectional one. These promoters are present in head-to-head class of genes whose TSS (Transcription Start Site) are located at the distance from 0 to $2000 \mathrm{bp}$. About $10 \%$ of protein-coding genes are bidirectional in mammals. Furthremore, it was observed that many genes that are transcribed from bidirectional promoters possess functions or are involved in the same processes such as DNA reparation, chromatin stability etc. [13]. Recently, Yang et al. have explored the biological implication of the control of genome stability by bidirectional promoters and showed a high enrichment of bidirectional promoters in genes strongly associated with breast and ovarian cancer [14]. Trinklein et al. analyzed TSS of 23752 human genes and revealed that TSS of 1352 gene pairs $(11 \%)$ were localized less than $1 \mathrm{~kb}$ from each other. Besides, the 5'-ends of 315 pairs $(23 \%)$ were partially overlapped, whereas in the majority of bidirectional promoters (67\%) which did not overlap the distance between TSS was less than $300 \mathrm{bp}$. After the functional analysis in different cell lines it was shown that $90 \%$ of the analyzed promoters were active in both directions, and only $10 \%$ were active in only one direction. Most bidirectional promoters that were analyzed in the study of Trinklein et al. are CpG-rich, $77 \%$ of them have $\mathrm{CpG}$ islands and only $8 \%$ have TATA-sequence compared to $38 \%$ and $28 \%$ of unidirectional promoters respectively [15]. Bidirectional promoters containing TATA boxes consistently show an asymmetrical distribution favoring one TSS over the other [16]. The presence of DPE, Inr and BRE elements does not significally differ in bidirectional and unidirectional promoters [15-18]. According to another study, the $\mathrm{CpG}$ islands were found to be more prevalent in bidirectional $(90 \%)$ promoters as opposed to unidirectional ones $(45 \%)$. Moreover, it was shown that $\mathrm{CpG}$ islands of bidirectional promoters differ from these of unidirectional promoters and are more functional [16]. Neuron-specific genes are poor in bidirectional promoters, however, specific bidirectional promoters were found for nervous tissue (NBiPs). Novel bidirectional promoters showing divergent transcription of the novel and potentially brain-specific lncRNAs (long non-coding RNAs), are highly enriched in neuronal genes [19]. Previously, several authors have shown that bidirectional promoters are the major source of gene activation-associated non-coding RNAs in different cells in mammals [20].

The distance between the TSS of ITSNI and CRYZL1, which are annotated in GeneBank, is $623 \mathrm{bp}$ (Fig. 1). Thus, these genes are in the head-to-head position at the distance less than $2000 \mathrm{bp}$ that meet the requirements of the bidirectional promoter. Trinklein et al. in their work [15] also defined the promoter of the gene pair ITSN1/CRYZL1 as a bidirectional, but the DNA fragment they explored corresponds to the incomplete promoter region of ITSNI/CRYZL1, and does not cover the part of CRYZL1 gene. The explored fragment was $201 \mathrm{bp}$ long and located $10 \mathrm{bp}$ to the annotated TSS of ITSNI gene (Fig. 1) [15].

The ITSN1/CRYZL1 promoter is GC-rich and has no TATA-boxes. Using the UCSC Genome Browser 


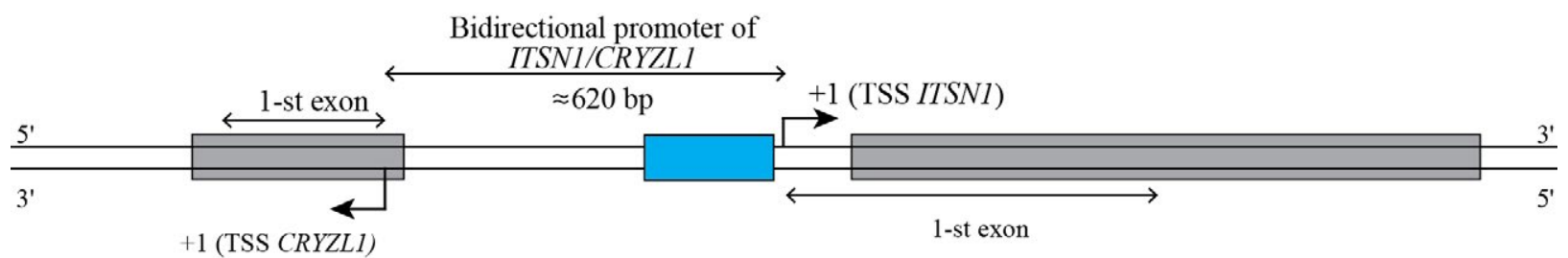

Fig. 1. Schematic representation of the bidirectional promoter of the gene pair ITSN1/CRYZL1. Blue box represents the promoter sequence explored by Trinklein et. al. [15]; gray boxes indicate CpG-islands in the ITSN1 and CRYZL1 genes.

on Human Dec. 2013 (GRCh38/hg38) Assembly we have identified a $\mathrm{CpG}$ island which comprises $196 \mathrm{bp}$ of the exon 1 and $773 \mathrm{bp}$ of the intron 1 of ITSN1 gene. CpG-island association is characteristic for bidirectional promoters. CRYZL1 also has a CpGisland which comprises exon 1 and a part of intron 1 of CRYZL1. The characteristics of the above-mentioned CpG-islands are specified in table 1. ITSN1/ CRYZL1 promoter analysis by RepeatMasker server has shown only one low complexity repeat of the G-rich subclass that comprises 71 bp before the annotated ITSN1 TSS.

Despite all these data the statement about the bidirectionality of the ITSN1/CRYZL1 promoter requires further experimental confirmation.

The ITSN1-S isoform is expressed in all tissues. No significant difference was detected in different tissues or pathological states. The CRYZL1 gene is poorly investigated and there is no data about its expression at the moment. However, if the bidirection-

\section{Table 1. CpG islands of ITSN1/CRYZL1 promoter}

\begin{tabular}{|l|l|l|}
\hline \multicolumn{1}{|c|}{ Gene } & \multicolumn{1}{|c|}{ CRYZL1 } & \multicolumn{1}{c|}{ ITSN1 } \\
\hline Position* & $33641571-$ & $33936694-$ \\
Band & 33641951 & 33937662 \\
Size CpG Island & $21 \mathrm{q} 22.11$ & $21 \mathrm{q} 22.11$ \\
CpG count & 381 & 969 \\
C count plus G count & 33 & 105 \\
Percentage CpG & 246 & 624 \\
Percentage C or G & $17.3 \%$ & $21.7 \%$ \\
Ratio of observed to expected & $64.6 \%$ & $64.4 \%$ \\
CpG & 0.85 & 1.05 \\
\hline
\end{tabular}

* - the positions are according to the UCSC Genome Browser on Human Dec. 2013 (GRCh38/hg38) Assembly site. ality of the ITSN1/CRYZL1 promoter is confirmed, we may suppose that the CRYZL1 product is also ubiquitously expressed and is implicated in clathrinmediated endocytosis, cell signaling etc., as the genes transcribed from bidirectional promotes are often involved in the same cellular processes.

Besides the main ITSN1 promoter, one more alternative promoter is identified in intron 5 . The nucleotide sequence, which promoter activity was investigated, is GC-rich. It has several consensuses that resemble TATA-box but all of them are non-functional which is confirmed by the luciferase test with the deletion mutants of this region as well as by the presence of three TSS found by the 5'-RACE [21], that does not correlate with the presence of the functional TATA-box [22]. The expression from the alternative promoter was detected in most analyzed tissues, however, at the much lower level comparing to the main promoter [21]. The analysis of this region by the RepeatMasker server revealed LINE1repeat of the L1MC5 subclass, that is almost entirely located at the additional 5'-sequence before the exon 6 which is crucial for the promoter activity and three SINE/Alu repeats (Table 2).

The ITSN1 gene is highly conservative. The bioinformatics analysis of the ITSN1 intron 5 of seven organisms (Macaca mulatta, Pan troglodytes, Bos taurus, Canis lupus familiaris, Rattus norvegicus, Mus musculus, Gallus gallus) for the repeat presence by the RepeatMasker server has shown that all of them have LINE1 repeat at the end of the intron 5. Moreover, only in chicken this repeat belongs to a CR1-H subclass repeat whereas in other organisms the repeats belong to L1MC5 was present in all others. 
Transcriptional and post-transcriptional regulation of the adaptor/scaffold protein gene ITSN1

Table 2. The repeats in the human ITSN1 promoter regions identified by the RepeatMasker bioinformatics server

\begin{tabular}{|c|c|c|c|c|c|c|c|}
\hline \multirow{2}{*}{ № } & \multicolumn{2}{|c|}{ Position at the intron 5* } & \multirow{2}{*}{ DNA strand } & \multirow{2}{*}{ Repeat name } & \multirow{2}{*}{ Repeat family } & \multicolumn{2}{|c|}{ Position at the repeat } \\
\cline { 2 - 3 } & start & end & & & & start & end \\
\hline 1 & 13354 & 13686 & + & AluJo & SINE/Alu & 1 & 305 \\
2 & 13778 & 14084 & - & AluJr4 & SINE/Alu & 2 & 306 \\
3 & 14157 & 14465 & + & AluSx1 & SINE/Alu & 1 & 310 \\
4 & 14484 & 14772 & - & L1MC5 & LINE/L1 & 7108 \\
\hline
\end{tabular}

* - position is represented according to the numeration from 1 to 14938 of the intron 5 nucleotides.

\section{Alternative splicing of the ITSN1 mRNA}

According to the recent data, human genome comprises about 25 thousand genes [23], which encode several hundred thousands of protein molecules with the specific function. This is implemented by many mechanisms the main of which are alternative splicing and alternative transcription. Alternative splicing is the process by which different pairs of splice sites are selected to produce multiple transcripts from a single gene. It is controlled by the concerted action of multiple cis-acting motifs and cognate trans-acting factors that promote or repress the assembly of productive splicing complexes (spliceosomes) at splice sites [24]. The EST analysis together with other bioinformatics computational methods revealed that minimum $70 \%$ of human genes have at least one alternatively spliced mRNA, and this proportion tends to increase [25].

ITSN1 gene has three main isoforms produced by alternative splicing with the attachment of three alternative 3'UTR (Fig. 2). Thus, as a result of the sequential connection of 41 exons (excluding the exon 30) the long isoform is produced which has a role in the specialized neuronal cell function and is expressed at high levels in these cells [26, 27, 28]. Its protein product comprises all eleven domains. As a result of the exon 30 splicing, a short isoform is formed, which is ubiquitously expressed and lacks three C-terminal domains (DH, $\mathrm{PH}$, and $\mathrm{C} 2$ ). Recently described ITSN1-22a isoform is produced by the exon $22 \mathrm{a}$ splicing. It is expressed in all analyzed tissues. ITSN1-22a is the shortest isoform as it lacks seven C-terminal domains but includes 116 aa of disordered sequence instead. This sequence is responsible for the AMPH1 SH3 domain binding, al- lows formation of homodimers and dimers with ITSN1-S, and regulates ITSN1 interaction with the ubiquitin ligase CBL [29].

The ITSN1 expression from the above-mentioned alternative promoter leads to the formation of the isoforms lacking the first EH domain. However, the existence of these isoforms at the protein level has not been proved yet.

Besides the alternative splicing of the 5'- and 3'ends, five in-frame splicing events are described for ITSN1, which change the amino acid composition of the protein (Fig. 2). The exon 20 splicing, which adds 15 bp coding 5 aa (VKGEW) in SH3A domain, is neuron-specific, and is controlled by nSR100/ SRRM4 (vertebrate- and neural-specific Ser/Arg repeat-related protein of $100 \mathrm{kDa}$ ) splicing regulator [30]. The exon 20 splicing is the most studied from these ITSN1 in-frame splicing events. It is known that the amount of its transcripts is gradually increased during embryonic development [31]. It is also shown that in mouse neurons both $(+20$ exon) and ( -20 exon) isoforms are expressed. It was demonstrated that inclusion of five amino acids increases N-SRC loop of the SH3A domain, which in turn regulates the interaction strength of SH3A with DNM1, CdGAP, SOS1 and c-CBL. Previously, the human glioblastoma cell line U-251 MG has been tested by RT-PCR for the presence of the exon 20 transcripts, but only isoforms lacking the exon 20 were detected [32]. Its expression in other cell lines and tumors was not investigated. We decided to check the presence of these isoforms in cancer tissues of different types. Interestingly, we have revealed that the amount of the exon 20-containing 


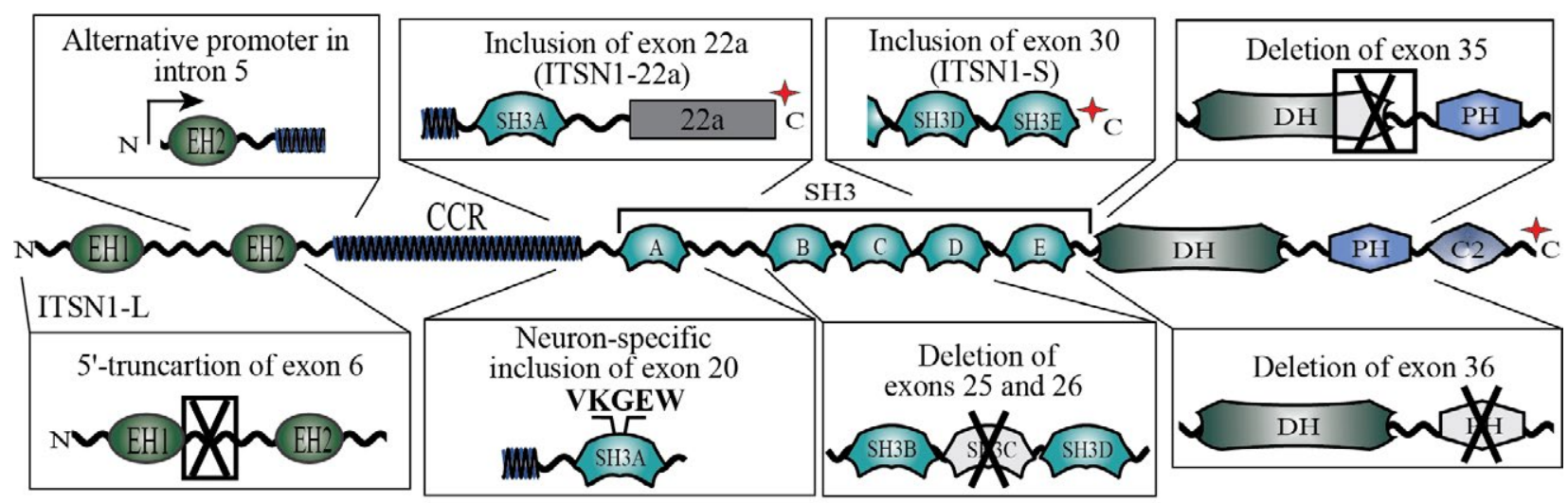

Fig. 2. Schematic representation of ITSN1 domain structure and alternative splicing events in human. Exon numbering is according to NM_003024.2. Asterisks indicate stop codons.

transcripts is decreased at different stages in the brain cancer specimen which could be explained by the decrease of neuron number in tumors. We have not detected the ITSN1 exon 20 containing isoforms either in renal or in ovarian tissues (Fig. 3 A-I, B).

Four more in-frame alternative splicing events described for ITSN1 are the following (Fig. 2):

1) 5 '-truncation of exon 6 which leads to the 37 aa shortening of the spacer between EH1 and EH2;

2) excision of the exons 25 and 26 which leads to the loss of the $\mathrm{SH} 3 \mathrm{C}$ domain;

$3)$ excision of exon $35($ ITSN1-LA35) which results in 25 aa truncation of the DH domain and shortening of the linker between $\mathrm{DH}$ and $\mathrm{PH}$ domains;

4) excision of exon 36 which leads to the PH domain loss.

The functional consequences of these alternative splicing events are currently unknown. We may suppose that the shortening of EH1-EH2 spacer and the $\mathrm{SH} 3 \mathrm{C}$ domain loss lead to the conformational changes which serve to regulate the interaction of $\mathrm{EH}$ and SH3 domains with their partners; whereas the excision of the exons 35 and 36 most likely regulate the guanine-nucleotide exchange activity of the DH domain. The combination of all the abovementioned alternative splicing events seems to be sporadic. Thus, for the isoform ITSN1-S all the reading frame combinations were cloned. For the ITSN1-L and alternative promoter isoforms only a few variants were obtained by cloning but this can be explained by cloning difficulties due to the big size of the products and/or their low expression. The expression of different transcripts significantly varies. For instance, the transcripts with the exon 6 truncation and the exon 36 excision make 3-5\% of total transcripts, whereas the transcripts with the exons 25-26 or the exon 35 excision make $20 \%$ and $10 \%$ respectively [11].

The expression analysis of ITSN1-L and ITSN1-L $\triangle 35$ isoform in different cancer types has shown the reduced transcripts number in brain tumors which is consistent with the results for exon 20 and can be explained by the same reasons (Fig. 3 A-II, C). Interestingly, these isoforms, previously considered as 'neuron-specific', were also detected in the non-neuronal tumors. Thus, the ITSN1-L and ITSN1-LA35 isoform transcripts were found in pheochromocytome, breast and prostate cancer samples (Fig. 4 A-I). Moreover, we have observed that in several samples of various glioblastoma stages, as well as pheochromocytome, breast and prostate cancers the ratio between ITSN1-L and ITSN1-LA35 transcripts was changed with the preference for the latter (Fig. 3 D, Fig. 4 C, F, I). However, there were no significant changes in isoform $22 \mathrm{a}$ and transcripts with or without the exons 25-26 exons expression (Fig. 3 A-III, IV). Thus, we can assume that cancer interferes with the alternative splicing mechanisms, which in particular lead to the changes in ITSN1 isoforms ratio. 
Previously we have demonstrated the expression of ITSN1-L in the cancer cell lines MDA-MB-231 and MCF-7 [5, 33]. Here we have shown by immunoprecipitation that ITSN1-L was expressed at the protein level in MDA-MB-231, a cancer cell line with invasive phenotype. We have used specific antibodies to the ITSN1 DH domain which bind only ITSN1-L isoform. ITSN1-L was detected with antiITSN1-EH antibodies in the precipitates obtained with anti-ITSN1-DH antibodies from the lysate of MDA-MB-231 cells (Fig. 5).

Besides the above-mentioned alternative splicing events which lead to the amino acid changes in
ITSN1 composition, a variety of alternative splicing events causing the frame shift with the early stopcodon appearance were described. Such transcripts are most likely degraded via nonsense-mediated mRNA decay (NMD) [11, 31].

To date there is no evidence on regulation of ITSN1 at mRNA level by changes in RNA transcription from promoters in various tissues and under various physiological states. Considering the previous data and our results we can suppose that the regulation of ITSN1 alternative isoforms quantity is probably performed via different splicing factors together with the mRNA stability control.
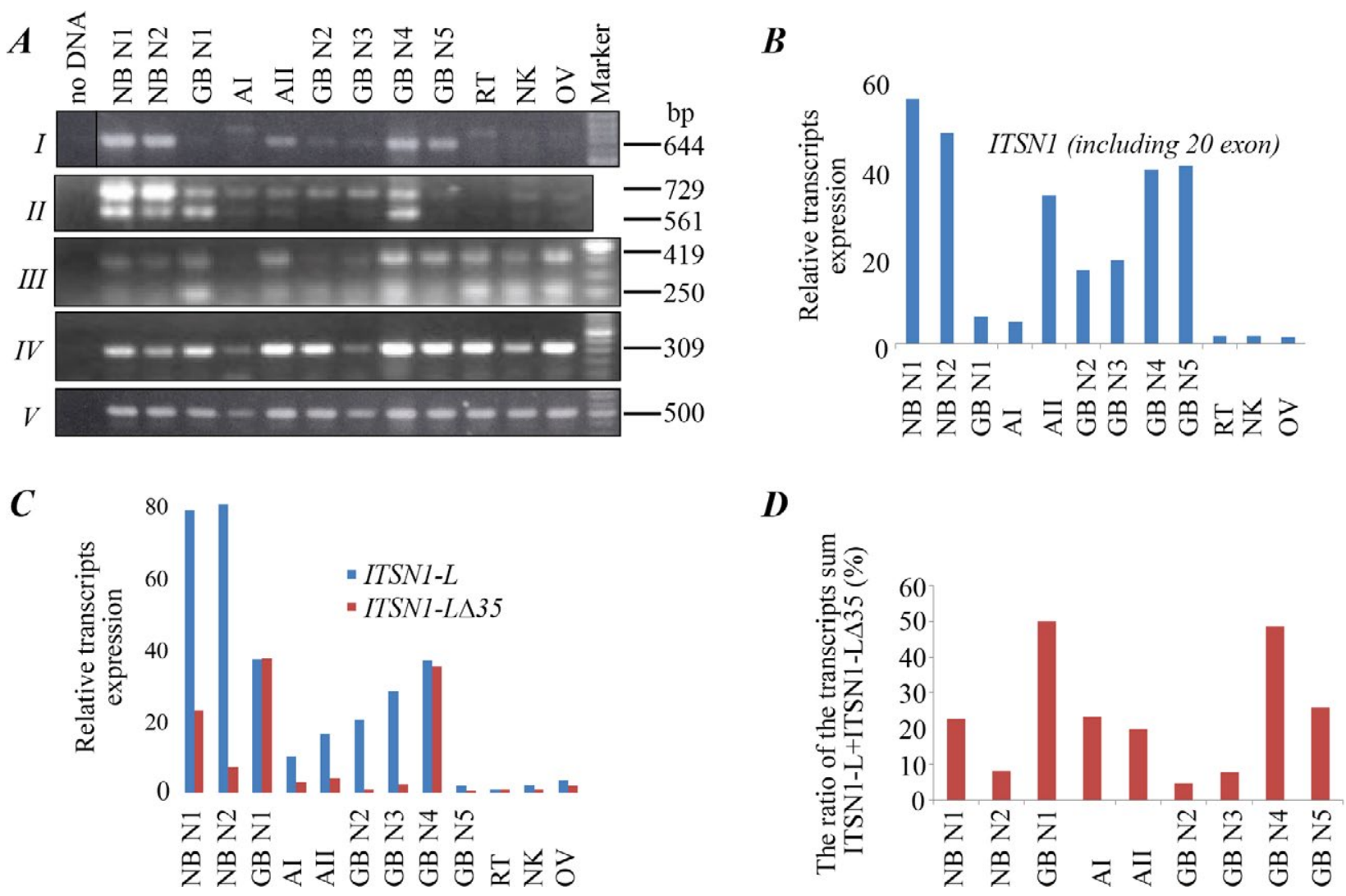

Fig. 3. Analysis of ITSN1 isoforms expression: A: I- isoforms ITSN1 containing the exon 20 using primers specific for the exons 20 (forward 2566-2587) and 23 (reverse 3184-3166); II-ITSN1-L and ITSN1-LA35 using primers specific for the exons 34 (forward 4394-4416) and 39 (reverse 5100-5122); III - isoforms ITSN1 with or without the exons 25-26 using primers specific for the exons 23 (forward 3112-3135) and 27 (reverse 3509-3530); IV-containing the exon 22a using primers specific for the exons 22 (forward 2583-2606) and 22a (reverse 2868-2891); $V$ - analysis of expression of control gene $\beta$-actin. $B$ : relative expression level of isoforms containing the exon 20; C: relative expression level of ITSN1-L and ITSN1-LA35 isoforms; D: portion of ITSN1-LA35 from total ITSN1-L isoforms expression. Densitometric measurements were performed using ImageJ software. NB - normal brain, GB - glioblastoma, $A$ - astrocytoma, RT - renal tumor, NK - normal kidney, OV - overy tumor 


\section{Breast cancer}

A

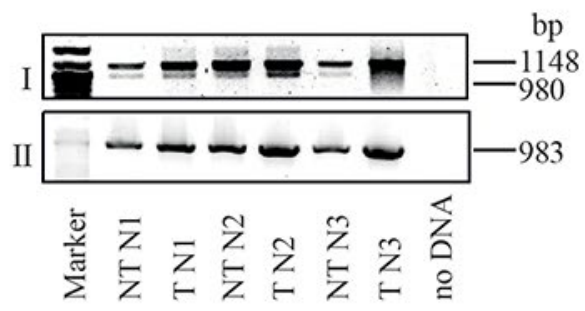

$\mathrm{D}$

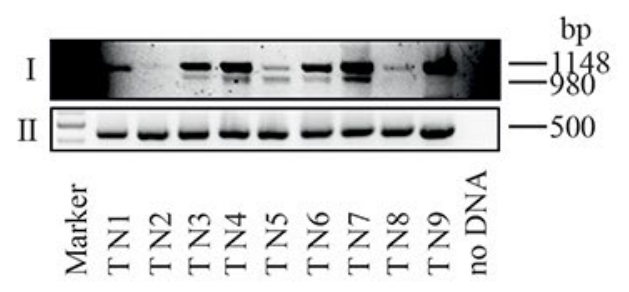

G

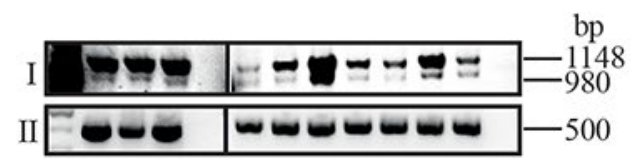

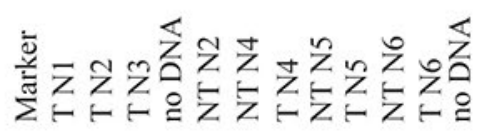

B

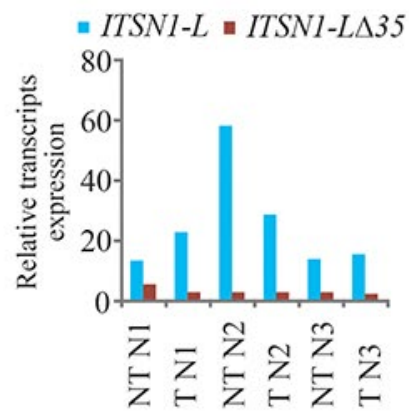

\section{Prostate cancer}
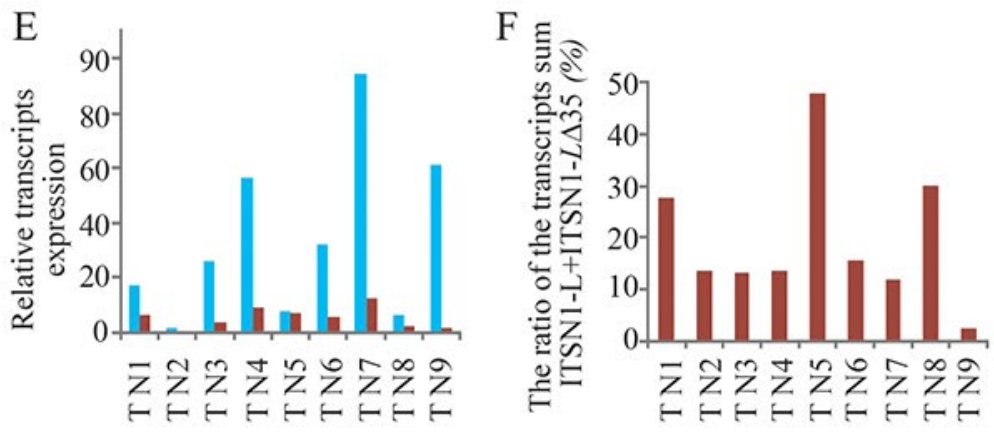

\section{Pheochromocytoma}

$\mathrm{H}$

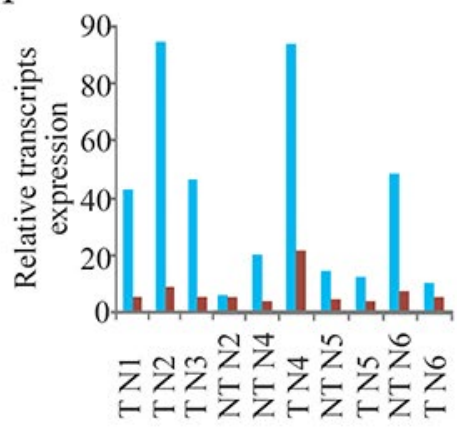

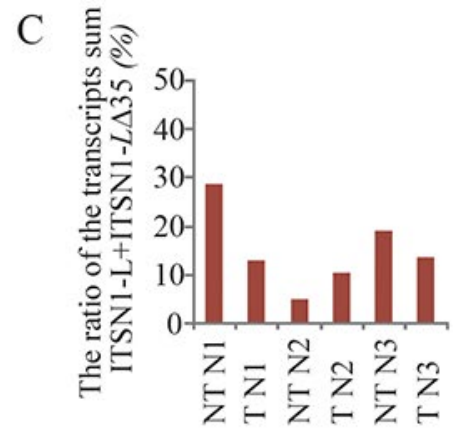

Fig. 4. Analysis of expression of ITSNI-L and ITSNI-LA35 isoforms in breast cancer, prostate cancer and pheochromocytoma: A, D, G: $I-I T S N 1-L$ and ITSN1-LA35 using primers specific for the exons 33 (forward 4160-4182) and 41 (reverse 5307-5285); II analysis of expression of control gene GAPDH - $983 \mathrm{bp}$ or $\beta$-actin - $500 \mathrm{bp}$. B, I, H: relative expression level of ITSN1-L and ITSN1$L \Delta 35$ isoforms; C, F, I: portion of ITSN1-LA35 from total ITSN1-L isoforms expression. Densitometric measurements were performed using ImageJ software. NT - normal tumor, $T$ - tumor.

\section{Prediction of microRNA target sites in $3^{\prime} U T R$ of ITSN1}

Despite the ITSN1 importance for endocytic process there is a limited information about its regulation at the post-transcriptional level by microRNAs (miRs). MicroRNAs are small non-coding RNA molecules 18-25 nt long that regulate post-transcriptionally more than $1 / 3$ of known genes [34]. In animals and 


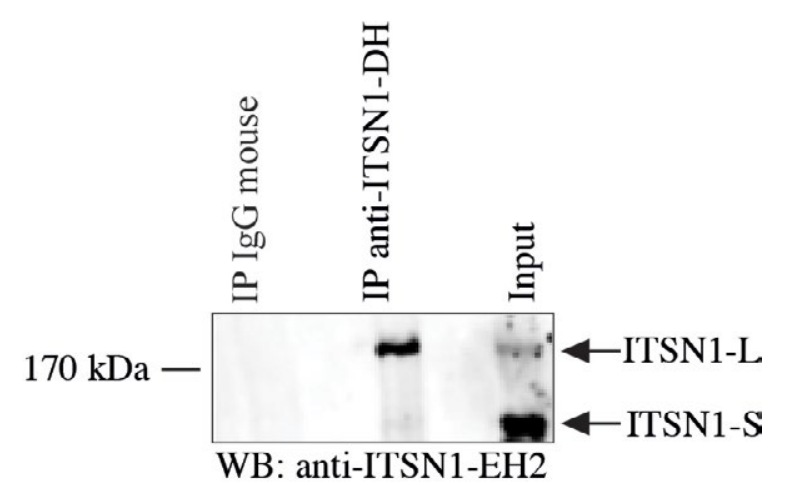

Fig. 5. Endogenous ITSN1- $L$ expression in invasive cancer cells. Lysates of MDA-MB-231 cells were subjected to immunoprecipitation using anti-ITSN1-DH antibodies and mouse IgG as a control. The precipitated proteins were eluted with Laemmli sample buffer and analyzed by Western blotting (WB). ITSN1L was detected using anti-ITSN1-EH antibodies.

humans mature miRs bind to the complementary sites in 3'-untranslated regions (3'UTRs) of their target mRNAs by 6-8 nt "seed" region on miRs 5'end thus negatively regulating gene expression [35]. Such mechanism is considered as main miR action. However, there is growing evidence of the positive regulation of gene expression as a result of miRs binding to the 5'UTRs or even protein coding regions of target mRNAs [36].

As described above, human ITSN1 has three main isoforms with alternative 3'UTRs - ITSN1-L, ITSN1-S and ITSN1-22a, with 3'UTRs length of $11566 \mathrm{nt}, 1510 \mathrm{nt}$ и $71 \mathrm{nt}$, respectively. [11, 29]. Despite the ITSN1 importance for endocytic process there is limited information about its regulation on post-transcriptional level by microRNAs. Currently, only one clear evidence of the ITSN1 post-transcriptional regulation expression is known: Lin et al showed negative changes in the ITSN1-S expression by miR-194 [37]. According to the comparatively long 3'UTRs of main ITSN1 isoforms and their involvement into several cellular processes it would have been intriguing if ITSN1 contains any other potential microRNA sites. To study this we used bioinformatical prediction methods as a fast way to analyze 3'UTR and narrow our search. Targetscan service is based on the search of target sites, which match the seed region of miRNAs, according to the site context and conservation, and known as one of the most accurate predictive servers [38, 39]. Thus, we used TargetScan v7.0 (August 2015 release) [39] as the main service for microRNA sites prediction in 3'UTRs of ITSN1 isoforms. We took into account only highly conservative microRNA target sites based on the prediction for several species including human, mouse, rat, chicken, and tropical frog.

The computational prediction of target sites in 3'UTR of ITSN1-S mRNA (GenBank ID NM_001001132, Ensembl ID ENST00000399352.1) revealed the unique conservative sites for more than 20 different microRNA families (Table 3). Among them, miR-19 family of microRNAs predicted to interact with two sites in 3'UTR of ITSN1-S located at 304-311 nt and 752-759 nt downstream from the start of 3'UTR, respectively; miR-181/4262 family microRNAs could bind two different sites located at 1013-1019 nt and 1405-1412 nt downstream from the start of 3'UTR. The only confirmed site for miR-194 is predicted as well. To refine our search we used MicroRNA.org, which is another web-service for the microRNA target sites prediction [40, 41]. MicroRNA.org confirmed most of the sites predicted by TargetScan (Table 3). MicroRNA sites predicted by MicroRNA.org but not identified by TargetScan may have less conservation thereby classified by TargetScan as less conservative and are excluded from our initial search. The obtained results indicate the factual existence of sites predicted above by TargetScan although further experimental verification is still needed.

On the contrary to ITSN1-S with 3'UTR of $1510 \mathrm{nt}$ and 19 predicted different sites for more than $20 \mathrm{miR}$ families, the brain-specific ITSN1-L isoform is characterized by an extremely long 3'UTR of $11561 \mathrm{nt}$ [11] with only few predicted microRNA target sites. Bioinformatical analysis by TargetScan v.7.0 identified only five conserved sites for microRNAs including site for the miR-30 family, which is the only common site for both main ITSN1 isoforms (Table 4). MicroRNA.org did not find any of the above-mentioned microRNAs while some other sites were identified. This could be explained by using ITSN1-L iso- 
Table 3. MicroRNA target sites predicted for ITSN1-S (NM_001001132; ENST00000399352.1) by TargetScan v.7.0 and MicroRNA.org

\begin{tabular}{|c|c|c|}
\hline MicroRNA Target Sites & $\begin{array}{l}\text { Position of target sites in 3'UTR ITSN1-S } \\
\text { according to TargetScan v. } 7.0^{\S}\end{array}$ & $\begin{array}{l}\text { Position of target site in 3'UTR ITSN1-S } \\
\text { according to MicroRNA.org \$ }\end{array}$ \\
\hline miR-193a-5p & $46-52 ; 411-418$ & - \\
\hline miR-190a-5p/190b & $59-65$ & - \\
\hline miR-34ac-5p/449a/449b-5p & $64-70$ & $67-70$ \\
\hline $\operatorname{miR}-326 / 330-5 p$ & $69-75^{* *}$ & $68-75$ \\
\hline miR-150-5p & $82-88$ & $82-88$ \\
\hline $\operatorname{miR}-224-5 p$ & $104-110^{* * *}$ & $106-113 ; 382-388$ \\
\hline let- $7 a-g-5 p / 98-5 p / m i R-4458 / 4500$ & $164-170$ & $164-170$ \\
\hline miR-202-3p & $164-170 * * * *$ & $164-170$ \\
\hline $\operatorname{miR}-371-5 p$ & $199-205^{* * *}$ & 199-205 \\
\hline miR-10ab-5p & $246-253$ & $246-253$ \\
\hline miR-19ab-3p & 304-311; 752-759 & 304-311; 752-759 \\
\hline miR-590-3p & $230-236 ; 329-336^{* * * *}$ & 329-336 \\
\hline miR-320a-d & - & $355-361$ \\
\hline miR-129-5p & $406-412$ & $229-235 ; 406-412$ \\
\hline miR-103a-3p/107 & $429-436$ & 428-435 \\
\hline $\mathrm{miR}-26 \mathrm{ab} / 1297$ & - & $477-483$ \\
\hline miR-141-3p/200a-3p & $502-509$ & $502-508$ \\
\hline $\operatorname{miR}-487 b$ & $717-723 * * *$ & $716-724$ \\
\hline miR-194-5p & 937-944 & 937-944 \\
\hline miR-375 & - & 987-993 \\
\hline miR-181a-d-5p/4262 & 1013-1019; 1405-1412 & $1013-1019 ; 1404-1412$ \\
\hline miR-92ab & - & $1032-1038$ \\
\hline miR-534 & - & $1046-1052$ \\
\hline miR-30a-e-5p & 1048-1055 & $1046-1054$ \\
\hline miR-128 & - & $1069-1074$ \\
\hline miR-140-3p.1 & $1069-1075$ & - \\
\hline miR-136 & $1096-1102 * *$ & $1095-1103$ \\
\hline $\operatorname{miR}-214$ & $1189-1195 * * * *$ & $1187-1196$ \\
\hline miR-15ab/16/195/424/427 & $1191-1197^{*}$ & $1191-1198$ \\
\hline $\operatorname{miR}-218-5 p$ & $1230-1237$ & - \\
\hline $\operatorname{miR}-488$ & $316-322 ; 1335-1341 * * *$ & $1335-1342$ \\
\hline miR-130ab/301ab/454 & $1380-1386^{*}$ & $1382-1389$ \\
\hline miR-200bc-3p/429 & 1388-1394 & 1388-1395 \\
\hline miR-101-3p.2 & $1447-1453$ & - \\
\hline
\end{tabular}

The sites with high conservation predicted by both servers are bolded. Conservation was indicated according to TargetScan v.7.0. For sites predicted by MicroRNA.org levels of conservation were not mentioned. Positions for sites complementary to seed regions of respective microRNAs are indicated. $\S$ - positions of predicted binding sites are showed according to nucleotide numbering from the 3'UTR first nucleotide of ITSN1-S from GenBank database, * - sites for poorly conserved miRNA families broadly conserved among vertebrates, ${ }^{* *}$ - sites for conserved miRNA families conserved among mammals, ${ }^{* * *}$ - sites for poorly conserved miRNA families conserved among mammals, $* * * *$ - sites for poorly conserved miRNA families. 
Table 4. MicroRNA target sites predicted for ITSN1-L (NM_003024; ENST00000381318.3) by TargetScan v.7.0 and MicroRNA.org

\begin{tabular}{|c|c|c|}
\hline MicroRNA Target Sites & 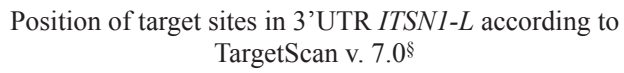 & $\begin{array}{l}\text { Position of target site in 3'UTR } \\
\text { ITSN1-L according to MicroRNA.org } \$\end{array}$ \\
\hline $\operatorname{miR}-125 a-5 p / 125-b$ & - & $17-24$ \\
\hline $\operatorname{miR}-134$ & $99-106 * * *$ & $100-107$ \\
\hline $\operatorname{miR}-28-5 \mathrm{p} / 708$ & $139-146^{* * *}$ & $139-146$ \\
\hline $\operatorname{miR}-384$ & $144-150 ; 6744-6750 * * *$ & $145-152$ \\
\hline $\operatorname{miR}-219-5 p$ & $159-165^{*}$ & $161-168$ \\
\hline $\operatorname{miR}-876-5 p$ & $259-265 * * *$ & $261-268$ \\
\hline $\operatorname{miR}-340$ & $345-351 ; 3697-3703 * * *$ & $345-351$ \\
\hline miR-33ab & $351-357 ; 4998-5004 *$ & $351-357$ \\
\hline $\operatorname{miR}-25 / 32 / 92 \mathrm{ab} / 363 / 367$ & $3779-3785^{*}$ & $353-359$ \\
\hline $\operatorname{miR}-342-3 p$ & $451-457 * * *$ & $451-458$ \\
\hline $\operatorname{miR}-185$ & $502-508 ; 3338-3345 * * *$ & $504-511$ \\
\hline miR-103/107 & $518-524 *$ & $517-525$ \\
\hline miR-300/381 & $643-649 ; 2258-2264 ; 3502-3509 ; 4298-4303 * * *$ & $642-650$ \\
\hline $\operatorname{miR}-199 a b-5 p$ & $670-676 ; 784-790 *$ & $670-677$ \\
\hline $\operatorname{miR}-615-3 p$ & $856-863 * * *$ & $856-863$ \\
\hline miR-181a-d & 915-921; 1514-1520; 4905-4911; 10967-10973* & $914-922$ \\
\hline miR-203-3p.1 & $944-951 * ; 1605-1612$ & 944-952 \\
\hline $\operatorname{miR}-653$ & $948-954 ; 10444-10450 * * * *$ & $949-957$ \\
\hline miR-135ab & $979-985 ; 6011-6017 *$ & $976-986$ \\
\hline $\operatorname{miR}-30-5 p$ & $1601-1607$ & - \\
\hline $\operatorname{miR}-137$ & $8527-8534$ & - \\
\hline miR-216-5p & $9417-9424$ & - \\
\hline miR-182-5p & $11118-11125$ & - \\
\hline
\end{tabular}

The sites with high conservation predicted by both servers are bolded. Conservation was indicated according to TargetScan v.7.0. For sites predicted by MicroRNA.org levels of conservation were not mentioned. Positions for sites complementary to seed regions of respective microRNAs are indicated. $\S$ - positions of predicted binding sites are showed according to nucleotide numbering from the 3'UTR first nucleotide of ITSN1-L from GenBank database, * - sites for poorly conserved miRNA families broadly conserved among vertebrates, $* *$ - sites for conserved miRNA families conserved among mammals, $* * *$ - sites for poorly conserved miRNA families conserved among mammals, $* * * *$ - sites for poorly conserved miRNA families.

Table 5. Sites for regulatory elements in canonical and alternative 5'UTRs of ITSN1, predicted by RegRNA 2.0 web server

\begin{tabular}{|l|c|c|c|}
\hline \multicolumn{2}{|c|}{ Canonical 5'UTR } & \multicolumn{2}{c|}{ Alternative 5'UTR } \\
\hline Type of Regulatory Element & $\begin{array}{l}\text { Position of predicted sites for } \\
\text { regulatory elements in 5'UTR } \\
\text { according to RegRNA 2.0§ }\end{array}$ & $\begin{array}{l}\text { Type of Regulatory Element } \\
\text { regulatory elements in 5'UTR } \\
\text { according to RegRNA 2.0* }\end{array}$ \\
\hline u1056_DISC2-RNA & $5-33$ & $\begin{array}{l}\text { u3712_snoRNA } \\
\text { U1995_snoRNA }\end{array}$ & $225-246$ \\
hsa-miR-149-3p & $153-174$ & - & $225-246$ \\
\hline
\end{tabular}

$\S$ - positions of predicted binding sites are shown according to the nucleotide numbering of canonical 5'UTR from GenBank database; * positions of predicted binding sites are shown according to the nucleotide numbering of alternative 5'UTR. 
form with incomplete 3'UTR of 1005 nt (GenBank ID NM 003024) instead of ITSNI- $L$ with fully annotated 3'UTR (Ensembl ID ENST00000381318.3).
At the same time, TargetScan could not predict any site found by MicroRNA.org at the region of $1005 \mathrm{nt}$ downstream from the start of ITSNI-L 3'UTR. Such

Table 6. Phosphorylation sites in human ITSN1 that were identified experimentally

\begin{tabular}{|c|c|c|}
\hline Residue & Location & Tissue (Condition) \\
\hline Ser203 & $\begin{array}{l}\text { EH1-EH2 } \\
\text { linker }\end{array}$ & $\begin{array}{l}\text { HeLa cells [52] } \\
\text { Breast and ovarian cancer [53] } \\
\text { HMLER cells [54] } \\
\text { Jurkat cells [55] } \\
\text { K562 cells [45] } \\
\text { Breast cancer cells [56] } \\
\text { Muscle [57] } \\
\text { A498 cells [58] }\end{array}$ \\
\hline Ser313 & $\begin{array}{l}\text { EH2-CCR } \\
\text { linker }\end{array}$ & $\begin{array}{l}\text { HeLa cells [52] } \\
\text { Non-small lung cancer cells [56] } \\
\text { Liver [59] } \\
\text { Jurkat cells [60] }\end{array}$ \\
\hline Ser315 & $\begin{array}{l}\text { EH2-CCR } \\
\text { linker }\end{array}$ & $\begin{array}{l}\text { HeLa cells [52] } \\
\text { Breast and ovarian cancer (Re- } \\
\text { gulated by cold ischemia) [53] } \\
\text { HMLER cells [54] } \\
\text { Jurkat cells [60] } \\
\text { Lung tumor [61] } \\
\text { 293E cells [62] } \\
\text { HeLa cells [45] } \\
293 \text { cells [63] }\end{array}$ \\
\hline Ser318 & $\begin{array}{l}\text { EH2-CCR } \\
\text { linker }\end{array}$ & Liver [64] \\
\hline Ser324 & $\begin{array}{l}\text { EH2-CCR } \\
\text { linker }\end{array}$ & Liver [64] \\
\hline Thr349 & $\begin{array}{l}\text { EH2-CCR } \\
\text { linker }\end{array}$ & $\begin{array}{l}\text { In vitro }\left(\mathrm{Ca}^{2+} / \text { calmodulin- }\right. \\
\text { dependent })[42]\end{array}$ \\
\hline Ser559 & CCR & $\begin{array}{l}\text { HeLa cells [52] } \\
\text { Breast and ovarian cancer (Re- } \\
\text { gulated by cold ischemia) [53] } \\
\text { Non-small lung cancer cells [56] } \\
{[55]} \\
293 \text { cells [65] } \\
\text { HeLa cells [66] }\end{array}$ \\
\hline Ser564 & CCR & Liver [64] \\
\hline Thr567 & CCR & $\begin{array}{l}\text { In vitro }\left(\mathrm{Ca}^{2+} / \text { calmodulin- }\right. \\
\text { dependent })[42]\end{array}$ \\
\hline
\end{tabular}

\begin{tabular}{|c|c|c|}
\hline Residue & Location & Tissue (Condition) \\
\hline Ser624 & CCR & $\begin{array}{l}\text { In vitro }\left(\mathrm{Ca}^{2+} / \text { calmodulin- }\right. \\
\text { dependent })[42] \\
\text { HeLa cells [52] } \\
\text { Basal breast cancer (Regulated } \\
\text { by cold ischemia) }[53] \\
\text { HeLa cells [66] }\end{array}$ \\
\hline Ser687 & CCR & $\begin{array}{l}\text { Luminal breast cancer [53] } \\
\text { HeLa cells }[66]\end{array}$ \\
\hline Ser735 & $\begin{array}{l}\text { CCR-SH3A } \\
\text { linker }\end{array}$ & HeLa cells [52] \\
\hline Tyr749 & $\mathrm{SH} 3 \mathrm{~A}$ & HeLa cells [52] \\
\hline Thr899 & $\begin{array}{l}\text { SH3A- } \\
\text { SH3B linker }\end{array}$ & $\begin{array}{l}\text { Non-small lung cancer cells [56] } \\
\text { Liver [64] } \\
\text { HeLa cells [67] }\end{array}$ \\
\hline Ser901 & $\begin{array}{l}\text { SH3A- } \\
\text { SH3B linker }\end{array}$ & $\begin{array}{l}\text { Liver [64] } \\
\text { HeLa cells [52] } \\
\text { ovarian cancer [53] } \\
\text { HeLa cells [67] } \\
\text { 293E cells [62] } \\
\text { GP293 cells (Transfected with } \\
\text { NPM-ALK) [68] }\end{array}$ \\
\hline Ser902 & $\begin{array}{l}\text { SH3A- } \\
\text { SH3B linker }\end{array}$ & $\begin{array}{l}\text { HeLa cells (M-phase) [45] } \\
\text { Liver [64] } \\
\text { HeLa cells [52] } \\
\text { Non-small lung cancer cells, } \\
\text { breast cancer cells [56] } \\
\text { Muscle [57] } \\
\text { Lung tumor [61] } \\
293 \text { cells [65] } \\
\text { HeLa cells [66] } \\
\text { GP293 cells (Transfected with } \\
\text { NPM-ALK) [68] } \\
\text { Hela cells. K562 cells [45] } \\
\text { SKBr3 cells [69] } \\
\text { HUES-7 cells [70] } \\
293 \text { cells [63] }\end{array}$ \\
\hline
\end{tabular}




\begin{tabular}{|c|c|c|}
\hline Residue & Location & Tissue (Condition) \\
\hline Ser904 & $\begin{array}{l}\text { SH3A- } \\
\text { SH3B linker }\end{array}$ & $\begin{array}{l}\text { In vitro (Ca }{ }^{2+} \text { calmodulin- } \\
\text { dependent) [42] } \\
\text { HeLa cells (G1 and M-phase) [45] } \\
\text { Liver [64] } \\
\text { HeLa cells (Cytosolic) [71] } \\
\text { HeLa cells [52] } \\
\text { ovarian cancer [53] } \\
\text { Non-small lung cancer cells, } \\
\text { breast cancer cells [56] } \\
\text { Muscle [57] } \\
\text { A498 cells (LPA regulated) [58] } \\
\text { Jurkat cells [60] } \\
\text { Lung tumor [61] } \\
293 \text { cells [65] } \\
\text { HeLa cells [66] } \\
\text { Jurkat cells [55] } \\
\text { K562 cells [45] } \\
\text { SKBr3 cells [69] } \\
\text { 293E cells [62] } \\
\text { HeLa cells [67] } \\
\text { Brain [72] } \\
\text { 293 cells (AT1aR transfection) } \\
\text { [73] } \\
\text { Liver [59] } \\
\text { U2OS cells [74] } \\
\text { HUES-7 cells [70] } \\
\text { hESCs [75] } \\
293 \text { cells [63] } \\
\text { WM115 cells [76] }\end{array}$ \\
\hline Tyr922 & SH3B & $\begin{array}{l}293 \text { cells (AT1aR transfection) } \\
{[73]}\end{array}$ \\
\hline Ser970 & SH3B & Luminal breast cancer [53] \\
\hline Ser976 & $\begin{array}{l}\text { SH3B- } \\
\text { SH3C linker }\end{array}$ & $\begin{array}{l}\text { HeLa [52] } \\
\text { Breast and ovarian cancer } \\
\text { (Regulated by cold ischemia) } \\
\text { [53] }\end{array}$ \\
\hline Thr977 & $\begin{array}{l}\text { SH3B- } \\
\text { SH3C linker }\end{array}$ & $\begin{array}{l}\text { HeLa cells [52] } \\
\text { Non-small lung cancer cells [61] }\end{array}$ \\
\hline Ser978 & $\begin{array}{l}\text { SH3B- } \\
\text { SH3C linker }\end{array}$ & $\begin{array}{l}\text { In vitro }\left(\mathrm{Ca}^{2+} / \text { calmodulin- }\right. \\
\text { dependent })[42]\end{array}$ \\
\hline
\end{tabular}

\begin{tabular}{|c|c|c|}
\hline Residue & Location & Tissue (Condition) \\
\hline & & $\begin{array}{l}\text { HeLa [52] } \\
\text { Muscle [57] } \\
\text { A498 cells [58] } \\
\text { Lung tumor [61] } \\
\text { Jurkat cells [55] } \\
\text { HeLa cells [67] } \\
293 \text { cells [63] }\end{array}$ \\
\hline Ser981 & $\begin{array}{l}\text { SH3B- } \\
\text { SH3C linker }\end{array}$ & $\begin{array}{l}\text { Liver [64] } \\
\text { HeLa cells [67] }\end{array}$ \\
\hline Ser983 & $\begin{array}{l}\text { SH3B- } \\
\text { SH3C linker }\end{array}$ & Lung tumor [61] \\
\hline Ser984 & $\begin{array}{l}\text { SH3B- } \\
\text { SH3C linker }\end{array}$ & HeLa cells [52] \\
\hline Ser986 & $\begin{array}{l}\text { SH3B- } \\
\text { SH3C linker }\end{array}$ & $\begin{array}{l}\text { HeLa cells (M-phase) [45] } \\
\text { HeLa cells [52] } \\
\text { Breast and ovarian cancer } \\
\text { (Regulated by cold ischemia) } \\
\text { [53] } \\
\text { HMLER cells [54] } \\
\text { Non-small lung cancer cells, } \\
\text { breast cancer cells [56] } \\
\text { HeLa cells [67] } \\
293 \text { cells [63] } \\
\text { K562 cells [45] }\end{array}$ \\
\hline Ser989 & $\begin{array}{l}\text { SH3B- } \\
\text { SH3C linker }\end{array}$ & $\begin{array}{l}\text { HeLa cells [52] } \\
\text { Luminal breast cancer [53] } \\
\text { Non-small lung cancer cells [56] } \\
\text { HeLa cells [67] }\end{array}$ \\
\hline Ser995 & $\begin{array}{l}\text { SH3B- } \\
\text { SH3C linker }\end{array}$ & Liver [64] \\
\hline Ser1137 & SH3D & $\begin{array}{l}\text { HeLa cells [52] } \\
\text { Breast and ovarian cancer [53] } \\
\text { Jurkat cells [55] } \\
\text { HeLa cells [45] } \\
\text { Brain [72] }\end{array}$ \\
\hline Thr1144 & $\begin{array}{l}\text { SH3D- } \\
\text { SH3E linker }\end{array}$ & $\begin{array}{l}\text { Liver [64] } \\
\text { HeLa cells [52] } \\
\text { Luminal breast cancer [53] } \\
\text { Jurkat cells [55] }\end{array}$ \\
\hline Tyr1208 & SH3E & HeLa cells [52] \\
\hline
\end{tabular}


results suggest an insufficient conservation of sites predicted by MicroRNA.org combined with somewhat different algorithms of prediction utilized by TargetScan and MicroRNA.org, which can be critical for predicting less probable sites.

In addition to the canonical impact of microRNAs on their targets as gene expression inhibition after binding to 3'UTRs of target mRNA, there is growing evidence of identifying functional microRNA target sites in coding regions as well as 5'UTRs of certain mRNAs that could enhance translation of target genes [36]. To predict any putative target sites for microRNAs and other regulatory elements in 5'UTRs of human ITSN1 we used web server RegRNA 2.0 for finding different types of regulatory elements. 5'UTRs of ITSN1-S and ITSN1-L are formed by first and second exons and each has the length of $268 \mathrm{nt}$. Since 5'UTRs of ITSN1-S and ITSN1-L are identical, the obtained data are applicable to both ITSN1 isoforms. The computational analysis revealed two types of regulatory elements: the site for u1056_DISC2-RNA (sites for hybridization with different types of non-coding RNAs except microRNAs) and one site for the human microRNA hsa-miR-149-3p (without indicating the level of conservation for microRNA target site) (Table 5).

The ITSN1 isoforms transcribed from the alternative promoter have an alternative $400 \mathrm{nt}$ 5'UTR [11]. To check if there are any different regulatory elements in this 5'UTR, we also used RegRNA 2.0, which predicted the sites for u3712_snoRNA and U1995_snoRNA, but did not find any microRNA target sites (Table 5).

In addition to the above-mentioned alternative 5'UTR, ITSN1 is known to have alternative splicing in the exons $1 \mathrm{a}$ and $1 \mathrm{~b}$ leading to the insertions of 62 or $125 \mathrm{bp}$ in canonical 5'UTR (187 bp in sum). The isoforms with these two exons and their combinations are expressed in the majority of analyzing tissues [11]. For $187 \mathrm{bp}$ insertion of the exons 1a and $1 \mathrm{~b}$, the computational analysis by RegRNA 2.0 showed no differences compared to the prediction for canonical 5'UTR of ITSN1. This suggests that, according to RegRNA 2.0, $187 \mathrm{bp}$ insertion added no new sites for the regulatory elements in intact 5'UTR sequence.

\section{Phosphorylation of ITSN1}

Post-translational modifications are the common way of regulation or modulation of the protein functions. Such modifications in the scaffold proteins can facilitate or inhibit the interaction with particular proteins, providing a mechanism for the control on molecular complex composition.

Large-scale studies of proteomes from different human tissues revealed a number of the ITSN1 posttranslational modifications, the vast majority of which is phosphorylation of serine or threonine residues (data from PhophositePlus database). In addition, our group have recently identified 5 sites of the $\mathrm{Ca}^{2+} /$ calmodulin-dependent serine/threonine phosphorylation within ITSN1 molecule [42]. However, either the functional roles of these phosphorylation events or the kinases, responsible for these modifications, have not been studies yet. The available data on phosphorylation of ITSN1 is summarized in Table 6 .

It is known that the phosphorylation sites are predominantly located in the intrinsically disordered regions of proteins $[43,44]$. As can be seen from the Table 6, in general, this is true for ITSN1 as well. However, the phosphorylated residues within the coiled-coil region, $\mathrm{DH}, \mathrm{PH}$ and $\mathrm{SH} 3$ domains have also been detected. In addition, the difference in the nature of serine/threonine and tyrosine phosphorylation can be observed. Whereas the majority of serine/threonine phosphorylation sites are located within the interdomain linkers, all the identified phosphorylated tyrosines belong exclusively to the $\mathrm{SH} 3$ domains. These differences reflect a distinct distribution of these amino acid residues in ITSN1 molecule. As can be seen from the frequency plots, the serine/threonine residues are more abundant and tend to form serine/threonine-rich clusters in the interdomain linkers, which are especially prominent in the EH2-CCR, SH3A-SH3B and SH3B-SH3C linkers (Fig. 6, middle panel). In contrast, the tyrosine residues are mostly individual and located within the structural domains (Fig. 6, lower panel). These differences can reflect distinct functional roles of the tyrosine versus serine/threonine phosphorylation in the protein functions. 
It is not clear whether the identified ITSN1 phosphorylation sites are phosphorylated permanently or in response to some conditions. We have shown that some kinases can phosphorylate ITSN1 in vitro in a $\mathrm{Ca}^{2+} /$ calmodulin-dependent manner, but it is currently not clear if this occurs in living cells as well [42]. Also, several sites were shown to be phosphorylated in HeLa cells in specific phases of the cell cycle, indicating their possible regulation by the cell cycle-dependent enzymes [45]. In another study, ITSN1 was shown to undergo the tyrosine phosphorylation in 293 cells in response to overexpression of tyrosine kinase Syk and Epstein-Barr virus protein LMP2A (Latent Membrane Protein 2A), but the sites of this phosphorylation were not identified [46]. On the other hand, the ITSN1 tyrosine phosphorylation in response to EGF stimulation in several human cell lines has not been detected, in contrast to its paralog ITSN2 [33].

It is predicted that not all of the phosphorylated sites identified in the large-scale proteomic studies are functional [47]. Therefore, since no functional role was reported for any of the identified ITSN1 phosphorylation sites, their functionality remains questionable. However, some possible outcomes from these phosphorylation events can be proposed. Several phosphorylation sites were identified within the coiled-coil region of ITSN1. It is known that the phosphorylation of threonine residues within coiledcoils can destabilize helices, while the phorphorylation of serine residues can both stabilize or destabilize them depending on the position [48, 49]. It can be expected that modifications in the coiled-coil regions can affect their ability to oligomerize or to form complexes with similar domains in other proteins. In support of this, it has been shown that the phosphorylation of coiled-coil region of the CRN2 protein affects its interaction with actin regulatory proteins, leading to the alterations of actin architecture and inhibition of the cell migration [50].

Most of the phosphorylation sites in the ITSN1 molecule are located in the interdomain linkers that are suggested to be intrinsically disordered. For today, the functions of ITSN1 interdomain linkers remain mostly unknown, although the linker between SH3A and SH3B domains was shown to interact with the $\alpha$ - and $\beta$-subunits of endocytic adapter protein AP2 [28]. Phosphorylation of the linkers indicates other potential functions of them. One possibility is

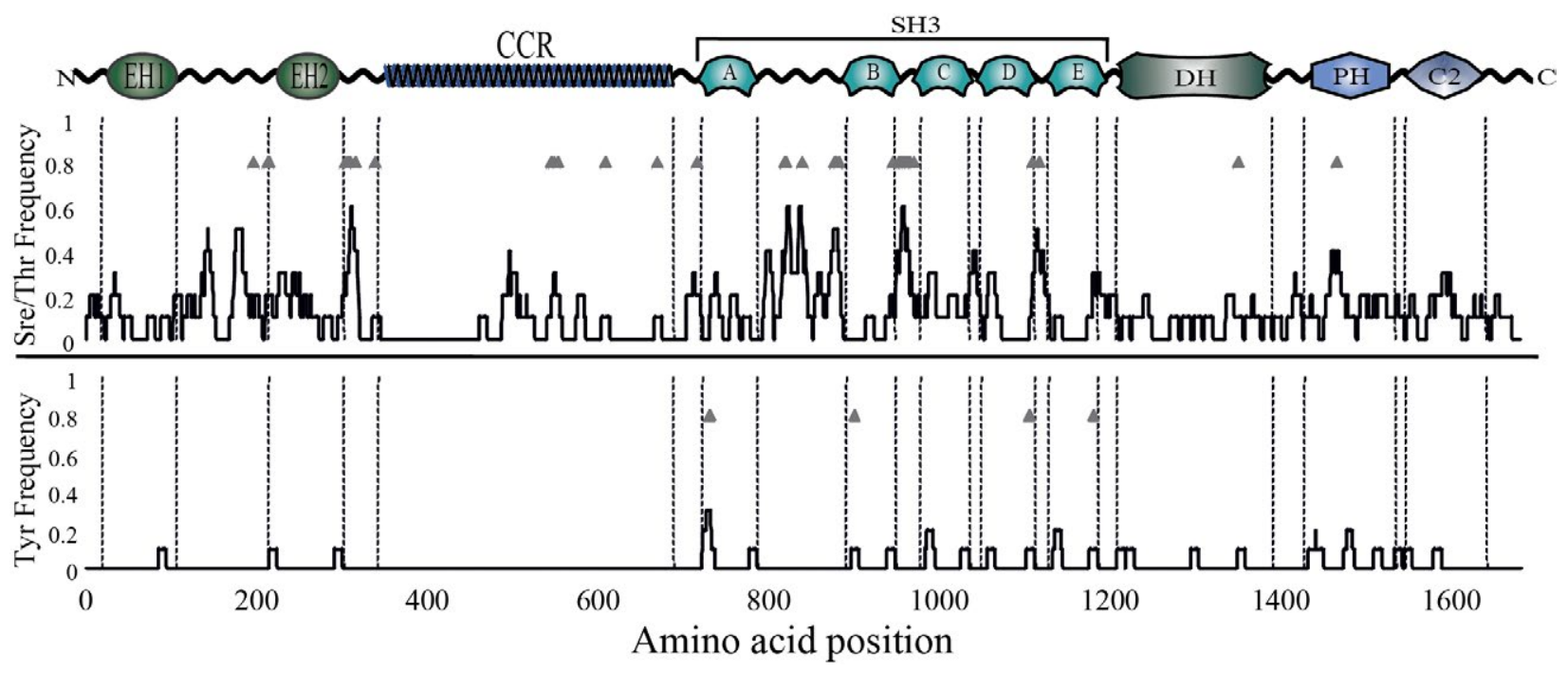

Fig. 6. Phosphorylation of human ITSN1. Upper panel - schematic representation of domain structure of ITSN1 molecule. Middle panel - distribution of serine/threonine residues in ITSN1 molecule. Each value of Ser/Thr frequency was calculated as frequency of serine/threonine per frame of 10 amino acid residues. Ser/Thr phosphorylation sites are marked by triangles. Lower panel - distribution of tyrosine (Tyr) residues in ITSN1 molecule (presented in the same way as serine/threonine distribution). 
that the phosphorylation of interdomain linkers can modify their structure and alter mutual orientation of ITSN1 domains, thereby affecting a higher order structure of the molecular complexes formed by ITSN1. Alternatively, the phosphorylation of interdomain linkers can create new interfaces for the protein-protein interactions. In support of this, the ELM server predicts that the Ser978 phosphorylation creates a motif for interaction with the 14-3-3 proteins and the WW domains of Pin proteins. Intriguingly, two large clusters of serine/threonine residues directly surround the SH3B domain, thereby, it is likely that these regions could regulate the SH3B binding properties. This domain interacts with endocytic protein endophilin in a manner that is different from a canonical SH3 domain binding mode [51]. A potential role of phosphorylation in regulation of this and other interactions is a topic for further investigations.

\section{Funding}

This work was supported as the research project in frames of the Agreement on Cooperation between the NAS of Ukraine and the National Center for Scientific Research of France (CNRS) "Human pathology, from the molecular to the cellular level", (0113U002831).

\section{Acknowledgments}

We thank Dr. V. Filonenko for the preparation of anti-ITSN1-DH antibodies.

\section{REFERENCES}

1. Pucharcós C, Fuentes JJ, Casas $C$, de la Luna S, Alcántara S, Arbonés ML, Soriano E, Estivill X, Pritchard M. Alusplice cloning of human Intersectin (ITSN), a putative multivalent binding protein expressed in proliferating and differentiating neurons and overexpressed in Down syndrome. Eur J Hum Genet. 1999;7(6):704-12.

2. Wilmot B, McWeeney SK, Nixon RR, Montine TJ, Laut J, Harrington $C A$, Kaye JA, Kramer PL. Translational gene mapping of cognitive decline. Neurobiol Aging. 2008;29(4):524-41.

3. Scappini E, Koh TW, Martin NP, O'Bryan JP. Intersectin enhances huntingtin aggregation and neurodegeneration through activation of c-Jun-NH2-terminal kinase. Hum Mol Genet. 2007;16(15):1862-71.
4. Ma Y, Wang B, Li W, Ying G, Fu L, Niu R, Gu F. Reduction of intersectin1-s induced apoptosis of human glioblastoma cells. Brain Res. 2010;1351:222-8.

5. Gryaznova T, Kropyvko S, Burdyniuk M, Gubar O, Kryklyva $V$, Tsyba L, Rynditch $A$. Intersectin adaptor proteins are associated with actin-regulating protein WIP in invadopodia. Cell Signal. 2015;27(7):1499-508.

6. Snyder JT, Rossman KL, Baumeister MA, Pruitt WM, Siderovski DP, Der CJ, Lemmon MA, Sondek J. Quantitative analysis of the effect of phosphoinositide interactions on the function of Dbl family proteins. J Biol Chem. 2001;276(49): 45868-75.

7. Hussain NK, Yamabhai M, Ramjaun AR, Guy AM, Baranes D, O'Bryan JP, Der CJ, Kay BK, McPherson PS. Splice variants of intersectin are components of the endocytic machinery in neurons and nonneuronal cells. $J$ Biol Chem. 1999;274(22):15671-7.

8. Guipponi M, Scott HS, Chen H, Schebesta A, Rossier C, Antonarakis $S E$. Two isoforms of a human intersectin (ITSN) protein are produced by brain-specific alternative splicing in a stop codon. Genomics. 1998;53(3):369-76.

9. Tsyba L, Nikolaienko O, Dergai O, Dergai M, Novokhatska O, Skrypkina I, Rynditch A. Intersectin multidomain adaptor proteins: regulation of functional diversity. Gene. 2011;473(2):67-75.

10. Tsyba LO, Dergai MV, Skrypkina IYa, Nikolaienko OV, Dergai OV, Kropyvko SV, Novokhatska OV, Morderer DYe, Gryaznova TA, Gubar OS, Rynditch AV. ITSN protein family: regulation of diversity, role in signalling and pathology. Biopolym Cell. 2013; 29(3):244-51.

11. Kropyvko S, Gerasymchuk D, Skrypkina I, Dergai M, Dergai $O$, Nikolaienko $O$, Rynditch A, Tsyba L. Structural diversity and differential expression of novel human intersectin 1 isoforms. Mol Biol Rep. 2010;37(6):2789-96.

12. Nikolaienko O, Skrypkina I, Tsyba L, Fedyshyn Y, Morderer D, Buchman V, de la Luna S, Drobot L, Rynditch A. Intersectin 1 forms a complex with adaptor protein Ruk/ CIN85 in vivo independently of epidermal growth factor stimulation. Cell Signal. 2009;21(5):753-9.

13. Wakano C, Byun JS, Di LJ, Gardner K. The dual lives of bidirectional promoters. Biochim Biophys Acta. 2012; 1819(7):688-93.

14. Yang $M Q$, Koehly LM, Elnitski LL. Comprehensive annotation of bidirectional promoters identifies co-regulation among breast and ovarian cancer genes. PLoS Comput Biol. 2007;3(4):e72.

15. Trinklein ND, Aldred SF, Hartman SJ, Schroeder DI, Otillar RP, Myers RM. An abundance of bidirectional promoters in the human genome. Genome Res. 2004; 14(1):62-6.

16. Yang $M Q$, Elnitski $L L$. Diversity of core promoter elements comprising human bidirectional promoters. BMC Genomics. 2008;9 Suppl 2:S3. 
17. Yang MQ, Taylor J, Elnitski L. Comparative analyses of bidirectional promoters in vertebrates. BMC Bioinformatics. 2008;9 Suppl 6:S9.

18. Yang $M Q$, Elnitski LL. Prediction-based approaches to characterize bidirectional promoters in the mammalian genome. BMC Genomics. 2008;9 Suppl 1:S2.

19. Hu HY, He L, Khaitovich P. Deep sequencing reveals a novel class of bidirectional promoters associated with neuronal genes. BMC Genomics. 2014;15:457.

20. Uesaka M, Nishimura O, Go Y, Nakashima K, Agata K, Imamura $T$. Bidirectional promoters are the major source of gene activation-associated non-coding RNAs in mammals. BMC Genomics. 2014;15:35.

21. Kropyvko SV, Tsyba LO, Skrypkina IYa, Rynditch AV. Identification and functional analysis of an alternative promoter of human intersectin 1 gene. Biopolym Cell. 2010;26(2):115-20.

22. Kozak M. Pushing the limits of the scanning mechanism for initiation of translation. Gene. 2002;299(1-2):1-34.

23. Clamp M, Fry B, Kamal M, Xie X, Cuff J, Lin MF, Kellis M, Lindblad-Toh $K$, Lander ES. Distinguishing protein-coding and noncoding genes in the human genome. Proc Natl Acad Sci US A. 2007;104(49):19428-33.

24. Chen M, Manley JL. Mechanisms of alternative splicing regulation: insights from molecular and genomics approaches. Nat Rev Mol Cell Biol. 2009;10(11):741-54.

25. Ghigna $C$, Valacca $C$, Biamonti $G$. Alternative splicing and tumor progression. Curr Genomics. 2008;9(8):556-70.

26. Irie F, Yamaguchi $Y$. EphB receptors regulate dendritic spine development via intersectin, Cdc42 and N-WASP. Nat Neurosci. 2002;5(11):1117-8.

27. Nishimura T, Yamaguchi T, Tokunaga A, Hara A, Hamaguchi T, Kato K, Iwamatsu A, Okano H, Kaibuchi K. Role of numb in dendritic spine development with a Cdc42 GEF intersectin and EphB2. Mol Biol Cell. 2006;17(3):1273-85.

28. Pechstein A, Bacetic J, Vahedi-Faridi A, Gromova K, Sundborger A, Tomlin N, Krainer G, Vorontsova O, Schäfer JG, Owe SG, Cousin MA, Saenger W, Shupliakov O, Haucke V. Regulation of synaptic vesicle recycling by complex formation between intersectin 1 and the clathrin adaptor complex AP2. Proc Natl Acad Sci US A. 2010;107(9):4206-11.

29. Dergai M, Skrypkina I, Dergai O, Tsyba L, Novokhatska O, Filonenko V, Drobot L, Rynditch A. Identification and characterization of a novel mammalian isoform of the endocytic adaptor ITSN1. Gene. 2011;485(2):120-9.

30. Quesnel-Vallières $M$, Irimia M, Cordes SP, Blencowe BJ. Essential roles for the splicing regulator nSR100/SRRM4 during nervous system development. Genes Dev. 2015;29(7):746-59.

31. Tsyba L, Skrypkina I, Rynditch A, Nikolaienko O, Ferenets $G$, Fortna A, Gardiner K. Alternative splicing of mammalian Intersectin 1: domain associations and tissue specificities. Genomics. 2004;84(1):106-13.

32. Tsyba L, Gryaznova T, Dergai O, Dergai M, Skrypkina I, Kropyvko S, Boldyryev O, Nikolaienko O, Novokhatska O,
Rynditch $A$. Alternative splicing affecting the SH3A domain controls the binding properties of intersectin 1 in neurons. Biochem Biophys Res Commun. 2008;372(4):929-34.

33. Novokhatska O, Dergai M, Tsyba L, Skrypkina I, Filonenko $V$, Moreau J, Rynditch A. Adaptor proteins intersectin 1 and 2 bind similar proline-rich ligands but are differentially recognized by $\mathrm{SH} 2$ domain-containing proteins. PLoS One. 2013;8(7):e70546.

34. Lewis BP, Burge CB, Bartel DP. Conserved seed pairing, often flanked by adenosines, indicates that thousands of human genes are microRNA targets. Cell. 2005;120(1):15-20.

35. Bartel DP. MicroRNAs: target recognition and regulatory functions. Cell. 2009;136(2):215-33.

36. Ørom UA, Nielsen FC, Lund AH. MicroRNA-10a binds the 5'UTR of ribosomal protein mRNAs and enhances their translation. Mol Cell. 2008;30(4):460-71.

37. Lin DH, Yue P, Zhang C, Wang WH. MicroRNA-194 (miR194) regulates ROMK channel activity by targeting intersectin 1. Am J Physiol Renal Physiol. 2014;306(1):F53-60.

38. Lewis BP, Burge CB, Bartel DP. Conserved seed pairing, often flanked by adenosines, indicates that thousands of human genes are microRNA targets. Cell. 2005;120(1):15-20.

39. Agarwal V, Bell GW, Nam JW, Bartel DP. Predicting effective microRNA target sites in mammalian mRNAs. Elife. 2015;4.

40. Enright AJ, John B, Gaul U, Tuschl T, Sander C, Marks DS. MicroRNAtargets in Drosophila. Genome Biol. 2003;5(1):R1.

41. Betel D, Wilson M, Gabow A, Marks DS, Sander C. The microRNA.org resource: targets and expression. Nucleic Acids Res. 2008;36(Database issue):D149-53.

42. Morderer DYe, Nikolaienko OV, Rynditch A. V. Identification of Ca2+/calmodulin-dependent phosphorylation sites of endocytic scaffold ITSN1 by tandem mass spectrometry. Biopolym Cell. 2015;31(5):338-44.

43. Iakoucheva LM, Radivojac P, Brown CJ, O'Connor TR, Sikes JG, Obradovic Z, Dunker AK. The importance of intrinsic disorder for protein phosphorylation. Nucleic Acids Res. 2004;32(3):1037-49.

44. Collins MO, Yu L, Campuzano I, Grant SG, Choudhary JS. Phosphoproteomic analysis of the mouse brain cytosol reveals a predominance of protein phosphorylation in regions of intrinsic sequence disorder. Mol Cell Proteomics. 2008;7(7):1331-48.

45. Dephoure N, Zhou C, Villén J, Beausoleil SA, Bakalarski CE, Elledge SJ, Gygi SP. A quantitative atlas of mitotic phosphorylation. Proc Natl Acad Sci U S A. 2008;105(31):10762-7.

46. Dergai O, Dergai M, Skrypkina I, Matskova L, Tsyba L, Gudkova D, Rynditch A. The LMP2A protein of Epstein-Barr virus regulates phosphorylation of ITSN1 and Shb adaptors by tyrosine kinases. Cell Signal. 2013;25(1):33-40.

47. Lienhard GE. Non-functional phosphorylations? Trends Biochem Sci. 2008;33(8):351-2.

48. Szilák L, Moitra J, Krylov D, Vinson C. Phosphorylation destabilizes alpha-helices. Nat Struct Biol. 1997;4(2):112-4. 
49. Szilák L, Moitra J, Vinson C. Design of a leucine zipper coiled coil stabilized $1.4 \mathrm{kcal} \mathrm{mol}-1$ by phosphorylation of a serine in the e position. Protein Sci. 1997;6(6):1273-83.

50. Xavier CP, Rastetter RH, Blömacher M, Stumpf M, Himmel M, Morgan RO, Fernandez MP, Wang C, Osman A, Miyata $Y$, Gjerset RA, Eichinger L, Hofmann A, Linder S, Noegel AA, Clemen CS. Phosphorylation of CRN2 by CK2 regulates F-actin and Arp2/3 interaction and inhibits cell migration. Sci Rep. 2012;2:241.

51. Pechstein A, Gerth F, Milosevic I, Jäpel M, EichhornGrünig M, Vorontsova O, Bacetic J, Maritzen T, Shupliakov $O$, Freund $C$, Haucke $V$. Vesicle uncoating regulated by $\mathrm{SH} 3-\mathrm{SH} 3$ domain-mediated complex formation between endophilin and intersectin at synapses. EMBO Rep. 2015; 16(2):232-9.

52. Sharma K, D’Souza RC, Tyanova S, Schaab C, Wiśniewski JR, Cox J, Mann M. Ultradeep human phosphoproteome reveals a distinct regulatory nature of Tyr and Ser/Thr-based signaling. Cell Rep. 2014;8(5):1583-94.

53. Mertins P, Yang F, Liu T, Mani DR, Petyuk VA, Gillette MA, Clauser KR, Qiao JW, Gritsenko MA, Moore RJ, Levine DA, Townsend R, Erdmann-Gilmore P, Snider JE, Davies SR, Ruggles KV, Fenyo D, Kitchens RT, Li S, Olvera N, Dao F, Rodriguez H, Chan DW, Liebler D, White F, Rodland KD, Mills GB, Smith RD, Paulovich AG, Ellis M, Carr SA. Ischemia in tumors induces early and sustained phosphorylation changes in stress kinase pathways but does not affect global protein levels. Mol Cell Proteomics. 2014;13(7):1690-704.

54. Yi T, Zhai B, Yu Y, Kiyotsugu Y, Raschle T, Etzkorn M, Seo HC, Nagiec $M$, Luna RE, Reinherz EL, Blenis J, Gygi SP, Wagner G. Quantitative phosphoproteomic analysis reveals system-wide signaling pathways downstream of SDF-1/CXCR4 in breast cancer stem cells. Proc Natl Acad Sci USA. 2014;111(21):E2182-90.

55. Mertins P, Qiao JW, Patel J, Udeshi ND, Clauser KR, Mani DR, Burgess MW, Gillette MA, Jaffe JD, Carr SA. Integrated proteomic analysis of post-translational modifications by serial enrichment. Nat Methods. 2013;10(7):634-7.

56. Klammer $M$, Kaminski $M$, Zedler A, Oppermann $F$, Blencke S, Marx S, Müller S, Tebbe A, Godl K, Schaab C. Phosphosignature predicts dasatinib response in non-small cell lung cancer. Mol Cell Proteomics. 2012;11(9):651-68.

57. Lundby A, Secher A, Lage K, Nordsborg NB, Dmytriyev A, Lundby $C$, Olsen $J V$. Quantitative maps of protein phosphorylation sites across 14 different rat organs and tissues. Nat Commun. 2012;3:876.

58. Schreiber TB, Mäusbacher N, Kéri G, Cox J, Daub H. An integrated phosphoproteomics work flow reveals extensive network regulation in early lysophosphatidic acid signaling. Mol Cell Proteomics. 2010;9(6):1047-62.

59. Han $G$, Ye M, Liu H, Song C, Sun D, Wu Y, Jiang X, Chen R, Wang $C$, Wang $L$, Zou $H$. Phosphoproteome analysis of human liver tissue by long-gradient nanoflow LC coupled with multiple stage MS analysis. Electrophoresis. 2010;31(6): 1080-9.

60. Mayya V, Lundgren DH, Hwang SI, Rezaul K, Wu L, Eng JK, Rodionov $V$, Han $D K$. Quantitative phosphoproteomic analysis of $T$ cell receptor signaling reveals system-wide modulation of protein-protein interactions. Sci Signal. 2009; 2(84):ra46.

61. Schweppe DK, Rigas JR, Gerber SA. Quantitative phosphoproteomic profiling of human non-small cell lung cancer tumors. J Proteomics. 2013;91:286-96.

62. Hsu PP, Kang SA, Rameseder J, Zhang Y, Ottina KA, Lim D, Peterson TR, Choi Y, Gray NS, Yaffe MB, Marto JA, Sabatini DM. The mTOR-regulated phosphoproteome reveals a mechanism of mTORC1-mediated inhibition of growth factor signaling. Science. 2011;332(6035):1317-22.

63. Gauci S, Helbig AO, Slijper M, Krijgsveld J, Heck AJ, Mohammed $S$. Lys-N and trypsin cover complementary parts of the phosphoproteome in a refined SCX-based approach. Anal Chem. 2009;81(11):4493-501.

64. Bian Y, Song C, Cheng K, Dong M, Wang F, Huang J, Sun D, Wang L, Ye M, Zou H. An enzyme assisted RP-RPLC approach for in-depth analysis of human liver phosphoproteome. J Proteomics. 2014;96:253-62.

65. Christensen GL, Kelstrup CD, Lyngsø C, Sarwar U, Bøgebo R, Sheikh SP, Gammeltoft S, Olsen JV, Hansen JL. Quantitative phosphoproteomics dissection of seven-transmembrane receptor signaling using full and biased agonists. $\mathrm{Mol}$ Cell Proteomics. 2010;9(7):1540-53.

66. Olsen JV, Vermeulen M, Santamaria A, Kumar C, Miller ML, Jensen LJ, Gnad F, Cox J, Jensen TS, Nigg EA, Brunak S, Mann M. Quantitative phosphoproteomics reveals widespread full phosphorylation site occupancy during mitosis. Sci Signal. 2010;3(104):ra3.

67. Kettenbach AN, Schweppe DK, Faherty BK, Pechenick D, Pletnev AA, Gerber SA. Quantitative phosphoproteomics identifies substrates and functional modules of Aurora and Polo-like kinase activities in mitotic cells. Sci Signal. 2011;4(179):rs5.

68. Wu F, Wang P, Zhang J, Young LC, Lai R, Li L. Studies of phosphoproteomic changes induced by nucleophosmin-anaplastic lymphoma kinase (ALK) highlight deregulation of tumor necrosis factor (TNF)/Fas/TNF-related apoptosis-induced ligand signaling pathway in ALK-positive anaplastic large cell lymphoma. Mol Cell Proteomics. 2010;9(7):1616-32.

69. Imami K, Sugiyama N, Imamura H, Wakabayashi M, Tomita M, Taniguchi M, Ueno T, Toi M, Ishihama Y. Temporal profiling of lapatinib-suppressed phosphorylation signals in EGFR/HER2 pathways. Mol Cell Proteomics. 2012;11(12): 1741-57.

70. Van Hoof D, Muñoz J, Braam SR, Pinkse MW, Linding R, Heck AJ, Mummery CL, Krijgsveld J. Phosphorylation dynamics during early differentiation of human embryonic stem cells. Cell Stem Cell. 2009;5(2):214-26. 
71. Beausoleil SA, Jedrychowski M, Schwartz D, Elias JE, Villén J, Li J, Cohn MA, Cantley LC, Gygi SP. Large-scale characterization of HeLa cell nuclear phosphoproteins. Proc Natl Acad Sci US A. 2004;101(33):12130-5.

72. Herskowitz JH, Seyfried NT, Duong DM, Xia Q, Rees HD, Gearing M, Peng J, Lah JJ, Levey AI. Phosphoproteomic analysis reveals site-specific changes in GFAP and NDRG2 phosphorylation in frontotemporal lobar degeneration. J Proteome Res. 2010;9(12):6368-79.

73. Xiao K, Sun J, Kim J, Rajagopal S, Zhai B, Villén J, Haas W, Kovacs JJ, Shukla AK, Hara MR, Hernandez M, Lachmann A, Zhao S, Lin Y, Cheng Y, Mizuno K, Ma'ayan A, Gygi SP, Lefkowitz RJ. Global phosphorylation analysis of beta-arrestin-mediated signaling downstream of a seven transmembrane receptor (7TMR). Proc Natl Acad Sci USA. 2010;107(34):15299-304.

74. Raijmakers $R$, Kraiczek $K$, de Jong AP, Mohammed $S$, Heck $A J$. Exploring the human leukocyte phosphoproteome using a microfluidic reversed-phase-TiO2-reversed-phase high-performance liquid chromatography phosphochip coupled to a quadrupole time-of-flight mass spectrometer. Anal Chem. 2010;82(3):824-32.

75. Brill LM, Xiong W, Lee KB, Ficarro SB, Crain A, Xu Y, Terskikh A, Snyder EY, Ding $S$. Phosphoproteomic analysis of human embryonic stem cells. Cell Stem Cell. 2009;5(2):204-13.

76. Old WM, Shabb JB, Houel S, Wang H, Couts KL, Yen CY, Litman ES, Croy CH, Meyer-Arendt K, Miranda JG, Brown RA, Witze ES, Schweppe RE, Resing KA, Ahn NG. Functional proteomics identifies targets of phosphorylation by B-Raf signaling in melanoma. Mol Cell. 2009;34(1):115-31.

\section{Транскрипційна та постранскрипційна регуляція гена адапторного/скафолдного білка ITSN1}

С. В. Кропивко, О. С. Губар, Т. А. Грязнова,

Д. Е. Мордерер, Д. О. Герасимчук, Л. А. Сивак,

О. М. Грабовий, А. В. Риндич.

ITSN1 - адаптерний/скафолдний білок який приймає участь у різноманітних фізіологічних та патологічних клітинних процесах. Він має складну регуляцію експресії та багаточисельні білки партнери. Мета. Характеристика функціонування та регуляції експресії ITSN1 має важливе значення для розуміння ролі ITSN1 в житті клітини. Методи. Біоінформатичний аналіз, напівкількісний аналіз експресії за допомогою ЗТ-ПЛР, іммунопреципітація. Результати.
Ми описали та проаналізували промоторні регіони ITSN1, детектували альтернативно сплайсовані ізоформи ITSN1 на рівні мРНК та білка в різних зразках раку. За допомогою різноманітних біоінформатичних серверів ми виявили сайти зв'язування 3 мікроРНК, а також ми проаналізували сайти серин-, треонін- та тирозин-фосфорилювання білка ITSN1. Висновки. Ми отримали нові дані про експресію ITSN1 при патологіях. Крім того, ми показали можливість регуляції экспресії ITSN1 за допомогою мікроРНК та ролі фосфорилювання серину, треоніну и тирозину в регуляції взаємодії ITSN1 з білками партнерами.

Кл юч о в і с с о в а: ITSN1, двонаправлений промотор, альтернативний сплайсинг, мікроРНК, фосфорилювання.

\section{Транскрипционная и постранскрипционная регуляция гена адапторного/скафолдного белка ITSN1}

С. В. Кропивко, О. С. Губарь, Т. А. Грязнова, Д. Е. Мордерер, Д. А. Герасимчук, Л. А. Сивак, А. Н. Грабовой, А. В. Рындич.

ITSN1 - адапторный/скафолдный белок который принимает участие в различных физиологических и патологических клеточных процессах. Он имеет сложное регулирование экспрессии и многочисленные белки партнеры. Цель. Характеристика функционирования и регуляция экспрессии ITSN1 имеет важное значение для понимания роли ITSN1 в жизни клетки. Методы. Биоинформатический анализ, полуколичественный анализ экспрессии с помощью ОТ-ПЦР, иммунопреципитация. Результаты. Мы описали и проанализировали промоторные области ITSN1, детектировали альтернативно сплайсированные изоформы ITSN1 на уровне мРНК и белка в разных образцах рака. С помощью различных биоинформатических серверов мы определили сайты связывания с микроРНК, также мы проанализировали сайты серин-, треонин- и тирозин-фосфорилирования белка ITSN1. Выводы. Мы получили новые данные про экспрессию ITSN1 при патологиях. Кроме того, мы показали возможность регуляции экспрессии ITSN1 с помощью микроРНК и потенциальной роли фосфорилирования серина, треонина и тирозина в регуляции взаимодействия ITSN1 с белками партнерами.

Кл юче в ы е сл ов а: ITSN1, двунаправленный промотор, альтернативный сплайсинг, микроРНК, фосфорилирование.

Received 08.05.2016 